2. Echevarria C, Anwar GA, Parker S, et al. Risk disclosure prior to bronchoscopy. Thorax 2010;65:277-8.

3. General Medical Council. Consent: patients and doctors making decisions together. General Medical Council UK, 2008.

\section{Author's response: 'risk disclosure prior to bronchoscopy'-Bianchi et al}

We are grateful to Dr Bianchi and colleagues for their interest in our study. ${ }^{1}$ They argue that 'knowledge of local and even personal bronchoscopic practice and performance' is necessary to determine the level of risk to the patient from the procedure and hence the degree of information that must be provided. ${ }^{2}$ This is certainly true if there is reason to believe that the risks in an institution or for an individual differ significantly from the norm-in either direction.

A database, such as that used in the Sheffield Teaching Hospitals, for recording complications following bronchoscopy is a valuable resource for auditing outcomes and quality assurance. However, one must be cautious when interpreting the absence of a serious complication in any given series. Hanley and Lippman-Hand, in a now-classic paper, described the 'rule of three' for such series: if none of $\mathrm{n}$ patients showed the event of interest, we can be $95 \%$ confident that the chance of this event is at most $3 / \mathrm{n}^{3}{ }^{3}$ For example, the Sheffield data showing no death with 1261 fibreoptic bronchoscopies translate into a $95 \%$ confidence limit ranging from zero to an upper limit of 1 death in 420 procedures (Clinicians may find the other implication of using $\mathrm{CI}$-that occurrence of an uncommon complication is not of itself an evidence of poor performance-more comforting). The absence of an uncommon complication in a personal or an institutional series will not of itself help the clinician strike the difficult balance between providing too much and too little risk information.

\section{Shaun T O'Keeffe, Mateen Uzbeck, Colin Quinn}

Galway University Hospitals, Ireland

Correspondence to Shaun T O'Keeffe, Galway University Hospitals, Unit 4, Galway, Ireland; sokanc@iolfree.ie

Competing interests None.

Provenance and peer review Not commissioned; not externally peer reviewed.

Accepted 24 September 2010

Published Online First 30 October 2010

Thorax 2011:66:358. doi:10.1136/thx.2010.151761

\section{REFERENCES}

1. Uzbeck M, Quinn C, Saleem I, et al. Randomised controlled trial of the effect of standard and detailed risk disclosure prior to bronchoscopy on periprocedure anxiety and satisfaction. Thorax 2009;64:224-7

2. Bianchi SM, Saha S, Anderson P. Risk disclosure prior to bronchoscopy. Thorax 2010. Published online first: doi:10.1136/thx.2010.150391.
3. Hanley JA, Lippman-Hand A. If nothing goes wrong, is everything all right? Interpreting zero numerators. JAMA 1983;249:1743-5.

\section{Factors that predict failure in home management of an acute exacerbation of COPD}

There is increasing interest in managing patients with non-severe acute exacerbation of chronic obstructive pulmonary disease (AECOPD) in the community. Hospital at Home and COPD Outreach programmes facilitate discharge of patients that would otherwise require hospital admission and have been shown to reduce hospital stay, ${ }^{1}$ readmission ${ }^{2}$ and healthcare costs without compromising patient care and satisfaction. ${ }^{3}$ Despite the human and health-related benefits associated with home services, $\sim 30 \%$ of patients relapse within 8 weeks, requiring hospital readmission. ${ }^{2}$ factors that predict relapse in these patients, we prospectively studied consecutive admissions with AECOPD discharged to a COPD Outreach programme. Patients with an AECOPD who met specific criteria ${ }^{4}$ were enrolled within $24 \mathrm{~h}$ of presentation to hospital. At presentation demographics, number of hospitalisations in the previous year, oxygen use, vaccination status (pneumococcal and influenza) and smoking history were assessed. Breathlessness and quality of life scores were recorded and oxygen saturations and spirometry were measured. Rehospitalisation data were collected at day 14, 6 weeks and 3 months following discharge. Readmission for AECOPD was defined as hospitalisation for $>24 \mathrm{~h}$ and was assessed using hospital records.

Patient variables were analysed for their association with readmission by day 14 , 6 weeks and 3 months using $\chi^{2}$ or the Fischer exact test. Multivariate analyses to
In an effort to better understand the

evaluate for independent risk factors were performed using logistic regression with readmission as the categorical dependent variable. Admissions for reasons other than COPD were not included in the analyses.

In total, 349 admissions with AECOPD were enrolled in the study. There were 46 readmissions (13\%) for AECOPD to hospital by day $14,81(23 \%)$ by 6 weeks and 106 $(30 \%)$ by 3 months. The study had approximately equal numbers of males (49\%) and females (51\%), with a mean age of 69.2 years. Median $\mathrm{FEV}_{1}$ (forced expiratory volume in $1 \mathrm{~s}$ ) \% predicted was $46.43 \%$.

Univariate analysis is shown in table 1 . We found no association between readmission and age, gender, spirometry, quality of life score or length of index admission.

Multivariate analysis identified that hospitalisation in the previous year $(\mathrm{p}=0.03$, OR 2.26, CI 1.1 to 4.8 ) and a Borg score $\geq 3$ $(p=0.04$, OR 2.15, CI 1.0 to 4.6) predicted readmission by day 14 in $75 \%$ of cases. Longterm oxygen therapy $(p=0.001$, OR $3.28, C I$ 1.6 to 6.5$)$, pack-year history $\geq 50(p=0.008$, OR 3.13, CI 1.4 to 7.3) and Borg score $\geq 3$ $(\mathrm{p}=0.001$, OR 3.31, CI 1.6 to 6.8$)$ predicted 6 week admission in $68.9 \%$.

Our study identifies independent risk factors that are easy to assess, reproducible and can be carried out as early as arrival to hospital, allowing these patients to be identified early in their admission. A significant factor associated with early readmission was the level of dyspnoea reported by patients at the time of enrolment. This reflects the importance of the subjective symptom of breathlessness as a factor that drives patients to seek medical attention.

This is the first study to identify specifically the factors that are associated with rehospitalisation in exacerbations managed out of hospital. This management strategy will become increasingly important in reducing the costs associated with AECOPD

Table 1 Univariate analyses of association between independent variables and readmission

\begin{tabular}{|c|c|c|c|}
\hline Variable & Day 14 & Week 6 & Month 3 \\
\hline Admissions in previous year & $\begin{array}{l}\mathrm{p}=0.02 \\
\text { (OR } 2.3, \mathrm{Cl} 1.1 \text { to } 4.7 \text { ) }\end{array}$ & $\begin{array}{l}\mathrm{p}=0.014 \\
\text { (OR } 2.0, \mathrm{Cl} 1.2 \text { to } 3.5)\end{array}$ & $\begin{array}{l}\mathrm{p}=0.027 \\
(\mathrm{OR} 1.8, \mathrm{Cl} 1.0 \text { to } 3.0)\end{array}$ \\
\hline Long-term oxygen therapy & $\begin{array}{l}\mathrm{p}<0.05 \\
\text { (OR } 1.95, \mathrm{Cl} 0.9 \text { to } 3.8 \text { ) }\end{array}$ & $\begin{array}{l}\mathrm{p}<0.001 \\
(\mathrm{OR} 3.84, \mathrm{Cl} 2.2 \text { to } 6.7)\end{array}$ & $\begin{array}{l}\mathrm{p}<0.001 \\
\text { (OR } 3.5, \mathrm{Cl} 1.9 \text { to } 6.3 \text { ) }\end{array}$ \\
\hline Portable oxygen & $\begin{array}{l}p=0.51 \\
\text { (OR } 1.33, \mathrm{Cl} 0.6 \text { to } 2.9 \text { ) }\end{array}$ & $\begin{array}{l}p=0.02 \\
\text { (OR } 2.76, C l 1.5 \text { to } 5.1 \text { ) }\end{array}$ & $\begin{array}{l}\mathrm{p}<0.001 \\
\text { (OR } 3.28, \mathrm{Cl} 1.7 \text { to } 6.3 \text { ) }\end{array}$ \\
\hline Home nebuliser & $\begin{array}{l}\mathrm{p}=0.43 \\
\text { (OR } 1.38, \mathrm{Cl} 0.6 \text { to } 3.1 \text { ) }\end{array}$ & $\begin{array}{l}\mathrm{p}=0.36 \\
\text { (OR } 1.3, \mathrm{Cl} 0.71 \text { to } 2.5 \text { ) }\end{array}$ & $\begin{array}{l}\mathrm{p}=0.24 \\
\text { (OR } 1.4, \mathrm{Cl} 0.8 \text { to } 2.7 \text { ) }\end{array}$ \\
\hline $\begin{array}{l}\text { Oxygen saturation }<92 \% \text { on } \\
\text { room air }\end{array}$ & $\begin{array}{l}p=0.28 \\
\text { (OR } 1.51, \mathrm{Cl} 0.7 \text { to } 3.3 \text { ) }\end{array}$ & $\begin{array}{l}p=0.005 \\
\text { (OR 2.17, Cl } 1.4 \text { to } 3.3 \text { ) }\end{array}$ & $\begin{array}{l}\mathrm{p}=0.02 \\
\text { (OR } 1.7, \mathrm{Cl} 1.2 \text { to } 2.4 \text { ) }\end{array}$ \\
\hline Pack-year history $\geq 50$ & $\begin{array}{l}\mathrm{p}=0.78 \\
\text { (OR } 1.07, \mathrm{Cl} 0.35 \text { to } 3.3 \text { ) }\end{array}$ & $\begin{array}{l}p=0.03 \\
\text { (OR } 3.25, \mathrm{Cl} 1.5 \text { to } 6.9)\end{array}$ & $\begin{array}{l}\mathrm{p}=0.01 \\
\text { (OR } 2.86, \mathrm{Cl} 1.3 \text { to } 6.2 \text { ) }\end{array}$ \\
\hline Borg scale $\geq 3$ & $\begin{array}{l}\mathrm{p}=0.026 \\
\text { (OR } 2.47, \mathrm{Cl} 1.2 \text { to } 5.1)\end{array}$ & $\begin{array}{l}\mathrm{p}<0.001 \\
(0 R 3.23, \mathrm{Cl} 1.7 \text { to } 6.0)\end{array}$ & $\begin{array}{l}\mathrm{p}<0.001 \\
\text { (OR } 3.23, \mathrm{Cl} 1.7 \text { to } 6.1 \text { ) }\end{array}$ \\
\hline MMRC scale $\geq 3$ & $\begin{array}{l}\mathrm{p}=0.02(\mathrm{OR} 2.56, \mathrm{Cl} 1.1 \\
\text { to } 5.7)\end{array}$ & $\begin{array}{l}\mathrm{p}=0.01 \\
\text { (OR } 2.0, \mathrm{Cl} 1.1 \text { to } 3.6 \text { ) }\end{array}$ & $\begin{array}{l}p=0.01 \\
\text { (OR 2.0, Cl } 1.1 \text { to } 3.4 \text { ) }\end{array}$ \\
\hline $\begin{array}{l}\text { Vaccination status } \\
\text { (pneumococcal and influenza) }\end{array}$ & $\begin{array}{l}\mathrm{p}=0.65 \text { (OR 1.2, Cl } 0.58 \\
\text { to } 2.4)\end{array}$ & $\begin{array}{l}p=0.8 \\
\text { (OR } 1.1, \mathrm{Cl} 0.61 \text { to } 1.9 \text { ) }\end{array}$ & $\begin{array}{l}\mathrm{p}=0.83 \\
\text { (OR } 0.94, \mathrm{Cl} 0.55 \text { to } 1.6 \text { ) }\end{array}$ \\
\hline
\end{tabular}

Pack-year history, number of packets of cigarettes smoked per day $\times$ total number of years smoking; Borg scale refers to level of dyspnoea at enrolment; MMRC (modified Medical Research Council) scale $\geq 3$ refers to level of dyspnoea at enrolment. 